\title{
P01.55. Turmeric inhibits parathyroid hormone- related protein (PTHrP) secretion from human rheumatoid synoviocytes
}

\author{
J Frye ${ }^{2}$, B Timmermann ${ }^{1}$, J Funk ${ }^{2^{*}}$ \\ From International Research Congress on Integrative Medicine and Health 2012 \\ Portland, Oregon, USA. 15-18 May 2012
}

\section{Purpose}

Excessive production of parathyroid hormone-related protein (PTHrP) by tumor-like synoviocytes contributes to joint destruction in rheumatoid arthritis (RA). Having previously demonstrated that curcuminoid-only and essential oil-only fractions of turmeric prevent joint destruction in an animal model of RA, we hypothesized that synoviocyte PTHrP production could be one signaling pathway targeted by turmeric (Curcuma longa L.) in RA.

\section{Methods}

Two turmeric extracts were isolated from dried turmeric rhizomes and chemically characterized by HPLC, an essential oil-free curcuminoid-containing fraction and an essential oil-only fraction. Their effects on IL-1beta stimulated PTHrP secretion from human rheumatoid synoviocytes were assessed using a commercial PTHrP ELISA and primary cultures of synoviocytes isolated from patients with RA, as defined by the American College of Rheumatology.

\section{Results}

Both turmeric fractions inhibited IL-1 stimulated PTHrP secretion from human rheumatoid synoviocytes in a dose-dependent fashion. The curcuminoid-containing fraction, which had no effect on constitutive PTHrP secretion, inhibited IL- stimulated PTHrP secretion with a least effective concentration (LEC) of $3 \mathrm{ug} / \mathrm{ml}$. The essential oils, while slightly but significantly increasing constitutive PTHrP secretion, were potent suppressors of IL-1 stimulated PTHrP secretion ( $\mathrm{LEC}=1 \mu \mathrm{g} / \mathrm{ml})$.

${ }^{2}$ University of Arizona, Tucson, USA

Full list of author information is available at the end of the article

\section{Conclusion}

Curcuminoids and essential oils of turmeric are both potent suppressors of cytokine-stimualted PTHrP secretion from human rheumatoid synoviocytes. When coupled with our previous in vivo studies demonstrating protective effects of both extracts in an animal model of rheumatoid arthritis, these findings suggest that both secondary metabolites of turmeric may have medicinal effects in the treatment of rheumatoid arthritis.

\section{Author details}

${ }^{1}$ University of Kansas, Lawrence, USA. ${ }^{2}$ University of Arizona, Tucson, USA.

Published: 12 June 2012

doi:10.1186/1472-6882-12-S1-P55

Cite this article as: Frye et al:: P01.55. Turmeric inhibits parathyroid hormone-related protein (PTHrP) secretion from human rheumatoid synoviocytes. BMC Complementary and Alternative Medicine 2012 12(Suppl 1):P55.
Submit your next manuscript to BioMed Central and take full advantage of:

- Convenient online submission

- Thorough peer review

- No space constraints or color figure charges

- Immediate publication on acceptance

- Inclusion in PubMed, CAS, Scopus and Google Scholar

- Research which is freely available for redistribution
C Biomed Central

\section{Ciomed Central}

(c) 2012 Frye et al; licensee BioMed Central Ltd. This is an Open Access article distributed under the terms of the Creative Commons Attribution License (http://creativecommons.org/licenses/by/2.0), which permits unrestricted use, distribution, and reproduction in any medium, provided the original work is properly cited. 